\title{
Deriving phytoplankton size classes from satellite data: Validation along a trophic gradient in the eastern Atlantic Ocean
}

\author{
Vanda Brotas a,b,*, Robert J.W. Brewin a , Carolina Sá b, Ana C. Brito ${ }^{\text {a,b }}{ }^{\text {, Alexandra Silva b }}$, \\ Carlos Rafael Mendes b, ${ }^{\text {, Tânia Diniz }}{ }^{\text {, }}$, Manfred Kaufmann ${ }^{\text {c }}$, Glen Tarran ${ }^{\text {a }}$, Steve B. Groom ${ }^{\text {a }}$, \\ Trevor Platt ${ }^{a}$, Shubha Sathyendranath ${ }^{\mathrm{a}}$ \\ a Plymouth Marine Laboratory, Prospect Place, PL1 3DH Plymouth, UK \\ b Centro de Oceanografia, Faculdade de Ciências, Universidade de Lisboa, Campo Grande, 1749-016 Lisboa, Portugal \\ ' Universidade da Madeira, Funchal E' CIMAR/CIIMAR, Rua dos Bragas 177, P-4050-123 Porto, Portugal
}

\section{A R T I C L E I N F O}

\section{Article history:}

Received 9 June 2012

Received in revised form 16 January 2013

Accepted 10 February 2013

Available online 25 March 2013

\section{Keywords:}

Phytoplankton

Cell-size structure and abundance

Remotely-sensed chlorophyll-a

Intracellular chlorophyll-a content per size

class

Eastern North Atlantic

\begin{abstract}
A B S T R A C T
In recent years, the global distribution of phytoplankton functional types (PFT) and phytoplankton size classes (PSC) has been determined by remote sensing. Many of these methods rely on interpretation of phytoplankton size or type from pigment data, but independent validation has been difficult due to lack of appropriate in situ data on cell size.

This work uses in situ data (photosynthetic pigments concentration and cell abundances) from the north-east Atlantic, along a trophic gradient, sampled from 2005 to 2010, as well as Atlantic Meridional Transect (AMT) data for the same region, to test a previously developed conceptual model, which calculates the fractional contributions of pico-, nano- and micro-plankton to total phytoplankton chlorophyll biomass (Brewin et al., 2010). The application of the model proved to be successful, as shown by low mean absolute error between data and model fit. However, regional values obtained for the model parameters had some effect on the relative distribution of size classes as a function of chlorophyll-a, compared with the results according to the original model. The regional parameterisation yielded a dominance of micro-plankton contribution for chlorophyll-a concentrations greater than $0.5 \mathrm{mg} \mathrm{m}^{-3}$, rather than from $1.3 \mathrm{mg} \mathrm{m}^{-3}$ in the original model. Intracellular chlorophyll-a (Chla) per cell, for each size class, was computed from the cell enumeration results (microscope counts and flow cytometry) and the chlorophyll-a concentration for that size class given by the model. The median intracellular chlorophyll-a values computed were 0.004 , 0.224 and 26.78 pg Chla cell ${ }^{-1}$ for pico-, nano-, and micro-plankton respectively. This is generally consistent with the literature, thereby providing an indirect validation of the method based on pigments to assign size classes. Using a satellite-derived composite image of chlorophyll-a for the study area, a map of cell abundance was generated based on the computed intracellular chlorophyll-a for each size-class, thus extending the remote-sensing method for mapping size classes of phytoplankton from chlorophyll-a concentration to mapping cell numbers in each class. The map reveals the ubiquitous presence of pico-plankton, and shows that all size classes are more abundant in more productive areas.
\end{abstract}

(c) 2013 Elsevier Inc. All rights reserved.

\section{Introduction}

The use of ocean-colour remote sensing has greatly increased knowledge about spatial, seasonal and inter-annual variability of phytoplankton biomass as indexed by chlorophyll-a, at regional and global scales (e.g. Dandonneau et al., 2004; Devred et al., 2009; Platt \&

\footnotetext{
* Corresponding author at: Centro de Oceanografia, Faculdade de Ciências, Universidade de Lisboa, Campo Grande, 1749-016 Lisboa, Portugal. Tel.: + 351 217500156; fax: +351217500009 .

E-mail address: vbrotas@fc.ul.pt (V. Brotas).

1 Present address: Instituto de Oceanografia, Universidade Federal do Rio Grande (FURG), Av. Itália, Rio Grande, RS 96201-900, Brazil.
}

Sathyendranath, 2008; Yoder et al., 2010). However, to understand the role of phytoplankton in the ocean carbon cycle, other properties are required, in addition to their chlorophyll concentration.

Phytoplankton covers a wide spectrum of biological diversity (Bowler et al., 2009), encompassing taxonomic groups with distinct sizes, life cycles, turn-over rates, nutrient stoichiometry, biochemical composition and ecological requirements. Different phytoplankton groups perform an array of diverse functions in the marine ecosystem. In this context, phytoplankton functional types (PFT) have been defined to link certain phytoplankton groups (which can be polyphyletic) with specific biogeochemical functions (Nair et al., 2008). The number of defined PFT can vary according to the scientific question being addressed (Le Quéré et al., 2005), but calcifiers (coccolithophores), 
silicifiers (diatoms), nitrogen fixers (Trichodesmium and $\mathrm{N}_{2}$ fixing prokaryotes), pico-autotrophs (pico-eukaryotes, and cyanobacteria such as Prochlorococcus and Synechococcus) and DMS producers (e.g., autotrophic flagellates) are commonly considered.

The detection of PFT from space has been the subject of ocean-colour research in recent years (e.g. Hirata et al., 2011; Nair et al., 2008) with the aim of supplementing our understanding of biogeochemical cycles on a global scale (e.g. Blackford et al., 2004; Le Quéré et al., 2005). Two major bio-optical methods have been established: i) those based on distinctive spectral-characteristics of each group (e.g. Alvain et al., 2005; Ciotti \& Bricaud, 2006; Devred et al., 2011; Kostadinov et al., 2009; Sathyendranath et al., 2004); and ii) those based on the wellestablished relationships between cell-size and phytoplankton abundance (Brewin et al., 2010; Hirata et al., 2008, 2011; Uitz et al., 2006).

Such bio-optical methods have relied upon a combination of remote sensing and in situ data. The analysis of phytoplankton pigments by high performance liquid chromatography (HPLC), which allows the assessment of phytoplankton communities (Jeffrey et al., 2007), has been commonly used to complement bio-optical data, and pigment composition is now used routinely as an aid to infer phytoplankton size structure (Devred et al., 2011; Vidussi et al., 2001). Despite collection of in situ data being expensive and time consuming, the need to acquire more information on phytoplankton community structure, ecophysiological parameters or bio-optical properties, is identified by most authors as a major requirement to the further development of both remote sensing of PFT and ocean-biogeochemistry models (Brewin et al., 2011b; Hirata et al., 2012; Le Quéré et al., 2005; Raitsos et al., 2008).

Claustre (1994) defined an index for the proportion of "new producer" biomass in a phytoplankton community, based on the observation that chlorophyll-a concentration was linearly correlated with fucoxanthin and peridinin contents, and established a set of diagnostic pigments to define phytoplankton taxa. Later, Vidussi et al. (2001) used diagnostic pigments as size-class markers to derive pico-plankton $(<2 \mu \mathrm{m})$, nano-plankton $(2-20 \mu \mathrm{m})$ and micro-plankton $(>20 \mu \mathrm{m})$ components (Sieburth et al., 1978) of phytoplankton in the Mediterranean. In this implementation, micro-plankton included diatoms and dinoflagellates, nano-plankton comprise haptophytes, cryptophytes, chrysophytes, prasinophytes and chlorophytes, whereas pico-plankton, include the cyanobacteria Prochlorococcus and Synechococcus, as well as several other classes, designated under the general term of pico-eukaryotes, whose composition and diversity are poorly known (Worden \& Not, 2008). On account of its simplicity, the use of diagnostic pigments to derive algal size groups gained a wide acceptance in the marine community (Barlow et al., 2007; Bouman et al., 2005; Brewin et al., 2011b; Bricaud et al., 2004; Dandonneau et al., 2004; Taylor et al., 2011, amongst others). More recently, using a large in situ database of vertical pigment profiles, Uitz et al. (2006) performed an empirical parameterisation for inferring the vertical structure in phytoplankton size classes (PSC) from surface chlorophyll-a.

A size-based approach to phytoplankton functionality is not always fully satisfactory from a biogeochemical perspective (Nair et al., 2008). For example, diatoms are silicifiers and typically categorised as micro-phytoplankton, yet some diatoms fall into the nano-size range. Despite these smaller diatoms having the same biogeochemical function they are likely to respond differently with respect to size-based functionality (e.g., export production). There are also some examples of nano-phytoplankton of a similar size having a contrasting biogeochemical function (e.g., calcifiers and DMS producers). Despite this, many functions of phytoplankton, such as nutrient uptake, light absorption, metabolic rates and sinking are strongly related to size. The link between function and size has resulted in some biogeochemical models adopting a size-based representation of phytoplankton communities (Le Quéré et al., 2005 and references herein)

Brewin et al. (2010) developed a model to derive PSC from remotely-sensed chlorophyll-a concentration. In their approach,
Atlantic Meridional Transect (AMT) data and the Uitz et al. (2006) diagnostic pigment approach, adjusted to account for pico-eukaroytes in oligotrophic waters, were used to parameterise a conceptual model (Sathyendranath et al., 2001) and produce maps of pico-, nano- and micro-plankton at a global scale. In another study, the relationship between chlorophyll, PSC and seven PFT was statistically analysed from a large pigment database by Hirata et al. (2011), who determined, using SeaWiFS imagery, the relative abundance of PSC and PFT at the global scale.

An alternative approach was presented by Kostadinov et al. (2009, 2010), who developed a bio-optical algorithm that used the spectral shape of the back-scattering coefficient derived from remotely-sensed ocean-colour data to compute information on the particle size distribution (PSD). The abundance of total particles, partitioned into three size classes, was mapped at the global scale and then linked to the three size classes of phytoplankton in the open ocean.

Knowledge of phytoplankton cell abundance is important for the comprehension of oceanic primary production, as from cell numbers, estimates of cell biovolume can be done, which can be consequently converted into carbon units (e.g., Hillebrand et al., 1999). Information on cell abundance per size class at highly resolved spatial and temporal scales would be extremely valuable to address a number of issues, from carbon cycling to fisheries management. In a review paper, Finkel et al. (2010) pointed out that a shift of the phytoplankton community from dominance by pico-plankton to a dominance by nano- and micro-plankton is associated with a shift from a rapid-carbon-cycling pelagic food web to an increase in the biological pump, due to an increase of particulate matter sedimentation. There is a growing concern that the relative global distribution of pico-, nano- and micro-plankton, where pico-plankton dominates in oligotrophic stratified waters and micro-plankton in nutrient-rich waters, could be modified by climate variability (Brewin et al., 2012; Kostadinov et al., 2010).

Regarding the connection between phytoplankton structure and fisheries, the link between the dominance of larger phytoplankton cells and higher fisheries productivity has been made by Ryther (1969). According to Platt et al. (2007), although it has been difficult to prove the causal connections between properties of marine ecosystems and fisheries success, remote sensing is the appropriate tool to examine spatial and temporal variations of primary productivity, the first-order link between fisheries and the ecosystem that supports them.

In this paper, we have combined in situ data collected along a trophic gradient in the eastern North Atlantic Subtropical Gyre (NAST) province (Longhurst et al., 1995), with oligotrophic (Horseshoe seamounts), mesotrophic (Azores Islands) and eutrophic (upwelling Portuguese coast) areas, sampled from 2005 to 2010, as well as data from Atlantic Meridional Transect (AMT) cruises within the area $30-43^{\circ}$ North and $8.5-30^{\circ}$ West. Diagnostic pigment analysis, together with microscope cell counts and flow cytometry data from the area, were used in combination with a conceptual model of phytoplankton size structure (Brewin et al., 2010), to derive maps of size-fractionated phytoplankton cell counts in the eastern Atlantic.

The main objectives of this work were: (i) to parameterise the conceptual model of Brewin et al. (2010) to a specific region; and (ii) to use intracellular chlorophyll estimates for the three size-classes, computed from the in situ database, to map cell abundance from remotely-sensed chlorophyll-a.

\section{Methodology}

Data were collected from several cruises in the eastern North Atlantic during 2005 to 2010. Additionally, data from the Atlantic Meridional Transect (AMT) cruises 2-19, collected from 1996 to 2009, were provided by the British Oceanographic Data Centre (BODC), comprising photosynthetic pigments and cell enumeration from flow 
cytometry. A total of 1100 samples (including 381 AMT samples) were used in our analysis. Fig. 1 shows the study area and Table 1 summarises the relevant properties measured during the different cruises.

Analysis of phytoplankton pigments by HPLC on AMT data followed the methodology of Gibb et al. (2000). For the other cruises, the following method was used: water samples were filtered onto Whatman GF/F filters. Pigments were extracted with $2-5 \mathrm{ml}$ of 95\% cold-buffered methanol ( $2 \%$ ammonium acetate) for $30 \mathrm{~min}$ at $-20{ }^{\circ} \mathrm{C}$, in the dark. Pigment extracts were analysed using a Shimadzu HPLC comprising a solvent delivery module (LC-10ADVP) with system controller (SCL-10AVP), a photodiode array (SPD-M10ADVP), and a fluorescence detector (RF-10AXL). Two different protocols were used:

1) Chromatographic separation was carried out using a C18 column for reverse-phase chromatography (Supelcosil; $25 \mathrm{~cm}$ long; $4.6 \mathrm{~mm}$ in diameter; $5 \mu \mathrm{m}$ particles) and a $35 \mathrm{~min}$ elution programme. The solvent gradient followed Kraay et al. (1992) adapted by Brotas and Plante-Cuny (1996) with a flow rate of $0.6 \mathrm{ml} \mathrm{min}{ }^{-1}$ and an injection volume of $100 \mu \mathrm{l}$. This procedure was applied to samples from Cascais NR05, Nazaré 2006, Nazaré PG06 and Azores.

2) Chromatographic separation was carried out using a monomeric OS C8 column (Symmetry C8, $15 \mathrm{~cm}$ long, $4.6 \mathrm{~mm}$ in diameter, and $3.5 \mu \mathrm{m}$ particle size). The solvent gradient followed Zapata et al. (2000) with a flow rate of $1 \mathrm{ml} \mathrm{min}^{-1}$, an injection volume of $100 \mu \mathrm{l}$, and $40 \mathrm{~min}$ elution programme. This procedure was applied to samples from Horseshoe seamounts (cruises POS384 and HM09) and Nazaré 2010.

The first protocol was developed mostly for estuarine and coastal samples. It has significantly lower detection and quantification limits than the second one, as well as a shorter elution programme and a lower solvent flow rate, making it cheaper and faster. The second protocol has the advantage of discriminating chlorophylls $\mathrm{c} 1$ and $\mathrm{c} 2$, as well as monovinyl chlorophyll-a and divinyl chlorophyll-a (divinyl chlorophyll-a is present in Prochlorococcus, whereas all the other phytoplankton taxa contain monovinyl chlorophyll-a). Further details of both methods can be seen in Mendes et al. (2007) and Hooker et al. (2012).
A quality control filter was applied to all pigment data, following Aiken et al. (2009), which uses the relationship of accessory pigments (i.e., all carotenoids plus chlorophylls b and c) and total chlorophyll-a (the sum of monovinyl chlorophyll-a, divinyl chlorophyll-a and chlorophyllide a) to accept or eliminate particular samples or entire cruises.

For pico- and nano-plankton cell counting, samples from POS384 and HM09 cruises were collected in $3.5 \mathrm{ml}$ cryovials, preserved with formaldehyde, kept in liquid nitrogen during the cruise, and stored at $-80{ }^{\circ} \mathrm{C}$ until analysis. An Accuri C6 Flow Cytometer was used, following the procedure described in Tarran et al. (2006), but with a flow rate of $100 \mu \mathrm{min}^{-1}$ and a sample volume of $500 \mu$ l. Within the analysis it was possible to resolve Prochlorococcus, Synechococcus, pico-eukaryotes, coccolithophores, cryptophytes and other nanoeukaryotes. Flow cytometric cell counting in AMT samples is described in Tarran et al. (2006).

Microscope cell counts were performed on Azores and Cascais NR05 cruise samples using the Utermőhl technique, with samples preserved with neutralised formalin (2\%), in $100 \mathrm{ml}$ settling chambers (Silva et al., 2008). Scanning electron microscope images were obtained for some samples of POS384: water volumes of 2.5-4 1 from different depths were filtered through Nuclepore filters, dried at $40{ }^{\circ} \mathrm{C}$ in Petri dishes for $12 \mathrm{~h}$ and sealed with Parafilm ${ }^{\circledR}$ until observation in a JEOL JSM-5200LV microscope. Cell enumeration results, from flow cytometer and microscope counts were used to compute Intracellular chlorophyll-a concentrations (see below).

The size classes were assessed from pigment concentration using the method proposed by Vidussi et al. (2001), in which the fraction of each size class is given by the ratio of diagnostic pigments characteristic of the algal groups contributing to that size class to the sum of all seven diagnostic pigments, with weighting proposed by Uitz et al. (2006). Here, the weighted sum of all diagnostic pigments, equivalent to total chlorophyll-a is computed from the expression $C=\sum W_{i} P_{i}$, where $\mathrm{W}=\{1.41,1.41,1.27,0.35,0.6,1.01$ and 0.86$\}$, and $\mathrm{P}=\{$ fucoxanthin, peridinin, 19 'hexanoyloxyfucoxanthin, 19'butonoyloxyfucoxanthin, alloxanthin, chlorophyll $b+$ divinyl chlorophyll $b$ and zeaxanthin\}.

The following steps were performed: i) The fractions of chlorophyll-a concentrations associated with each size class were inferred from the relative concentration of the seven diagnostic

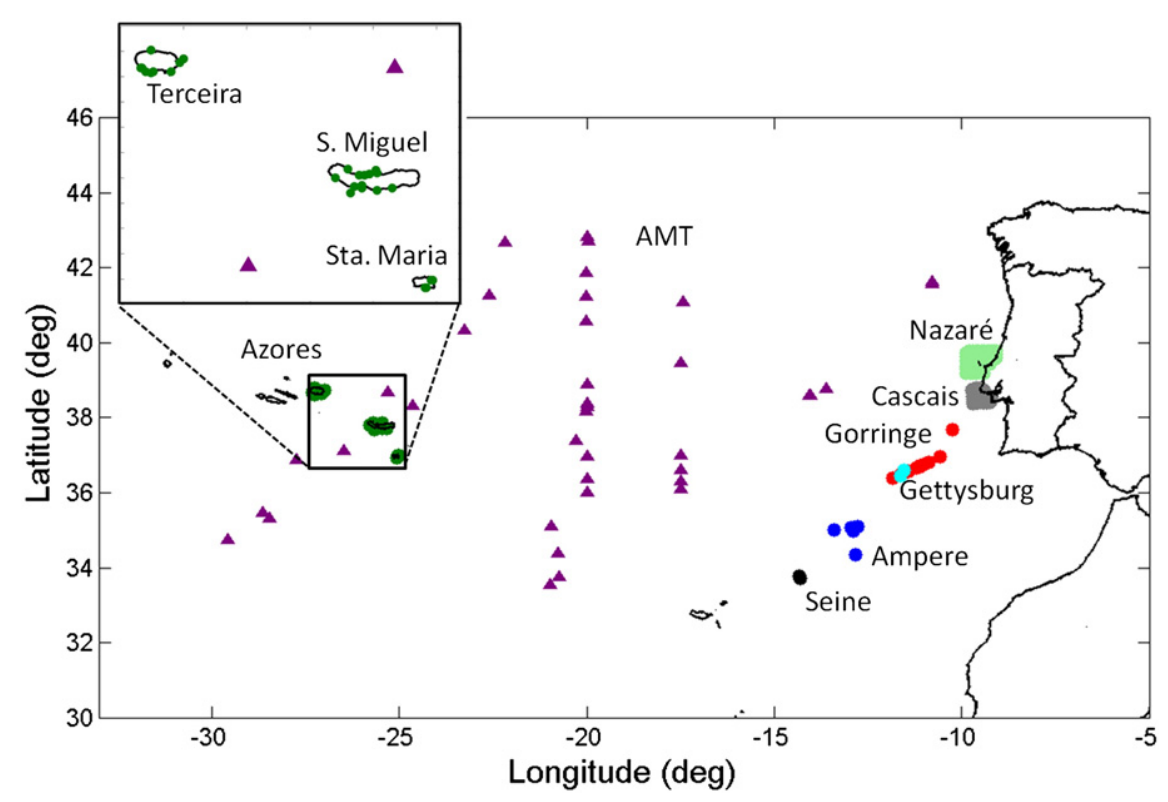

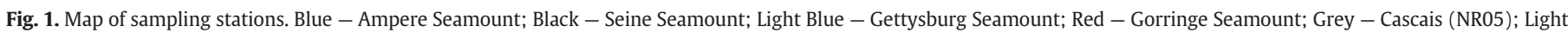
Green - Nazaré PG06, Nazaré 2006 and Nazaré 2010; Green - Azores; Purple - AMT cruises. 
Table 1

Summary of the cruises.

\begin{tabular}{|c|c|c|c|c|c|c|}
\hline Cruises/Data sets & $\begin{array}{l}\text { Latitude } \\
\text { Longitude W, } \\
\text { decimal degrees }\end{array}$ & Trophic status & Date & No. of stations & Observations & $\begin{array}{l}\text { HPLC } \\
\text { Flow cytometry (FC) } \\
\text { Cell counts (CC) }\end{array}$ \\
\hline $\begin{array}{l}\text { Horseshoe seamounts: } \\
\text { Seine, Ampere, Gettysburg } \\
\text { (POS384 cruise) }\end{array}$ & $\begin{array}{l}33.4^{\circ}-36.7^{\circ} \mathrm{N} \\
11.5^{\circ}-14.4^{\circ} \mathrm{W}\end{array}$ & Oligotrophic & 8-25 May 2009 & 15 & Profiles till $150 \mathrm{~m}$ & $\begin{array}{l}\text { HPLC } \\
\text { FC }\end{array}$ \\
\hline $\begin{array}{l}\text { Horseshoe seamounts: } \\
\text { Gorringe } \\
\text { (HM09 cruise) }\end{array}$ & $\begin{array}{l}36^{\circ}-37^{\circ} \mathrm{N} \\
10^{\circ}-12^{\circ} \mathrm{W}\end{array}$ & Oligotrophic & 2-6 June 2009 & 14 & Profiles till $100 \mathrm{~m}$ & $\begin{array}{l}\text { HPLC } \\
\text { FC }\end{array}$ \\
\hline $\begin{array}{l}\text { Azores } 2008 / 2009 \\
\text { S. Miguel } \\
\text { Santa Maria } \\
\text { Terceira }\end{array}$ & $\begin{array}{l}36.9^{\circ}-38.9^{\circ} \mathrm{N} \\
25.0^{\circ}-27.4^{\circ} \mathrm{W}\end{array}$ & Mesotrophic & $\begin{array}{l}\text { May-June } 2008 \\
\text { April-July } 2009\end{array}$ & $\begin{array}{l}27 \\
27\end{array}$ & Surface, 15 and $30 \mathrm{~m}$ & $\begin{array}{l}\text { HPLC } \\
\text { CC }\end{array}$ \\
\hline Nazaré 2006 & $\begin{array}{l}39.2^{\circ}-39.8^{\circ} \mathrm{N} \\
9.1^{\circ}-9.9^{\circ} \mathrm{W}\end{array}$ & $\begin{array}{l}\text { Upwelled } \\
\text { coast }\end{array}$ & 22 June-5 July 2006 & 92 & Surface & HPLC \\
\hline Nazaré 2010 & $\begin{array}{l}39.3^{\circ}-39.71^{\circ} \mathrm{N} \\
9.1^{\circ}-9.8^{\circ} \mathrm{W}\end{array}$ & & 6-18 March 2010 & 71 & Profiles till $50 \mathrm{~m}$ & HPLC \\
\hline Nazaré PG06 & $\begin{array}{l}\text { Fixed point } \\
39.61^{\circ} \mathrm{N} \\
9.29^{\circ} \mathrm{W}\end{array}$ & & $\begin{array}{l}10-11 \\
\text { Sept } 2006\end{array}$ & $\begin{array}{l}1 \\
\text { (24 h cycle })\end{array}$ & $5,50 \mathrm{~m}$ and $\mathrm{DCM}$ & HPLC \\
\hline Cascais NR05 & $\begin{array}{l}38^{\circ}-39^{\circ} \mathrm{N} \\
9^{\circ}-10^{\circ} \mathrm{W}\end{array}$ & Vicinity of Tagus river & 29 August-6 Sept 2005 & 228 & Surface, and DCM samples & $\begin{array}{l}\text { HPLC } \\
\text { CC }\end{array}$ \\
\hline $\begin{array}{l}\text { AMT } 2,3,4,6,8,10,12,13 \text {, } \\
\quad 14,15,18 \text { and } 19\end{array}$ & $\begin{array}{l}33^{\circ}-43^{\circ} \mathrm{N} \\
10^{\circ}-30^{\circ} \mathrm{W}\end{array}$ & Oligotrophic & 1996-2009 & 74 & Profiles till $150 \mathrm{~m}$ & $\begin{array}{l}\text { HPLC } \\
\text { FC for } \\
\text { AMT13, } 18 \text { and } 19\end{array}$ \\
\hline
\end{tabular}

pigments listed above, using a pico-eukaryote adjustment (see Brewin et al., 2010 and Hirata et al., 2011). The fractions were then multiplied by the in situ chlorophyll-a concentration to derive size-specific chlorophyll-a concentrations; ii) we then fitted the model developed by Brewin et al. (2010), which calculates the fractional contributions of the three phytoplankton size classes (micro-, nano- and picoplankton) as a function of total chlorophyll-a, to the whole in situ data (see Brewin et al., 2011a for details on how the model was fitted); and then iii) intracellular chlorophyll-a concentrations for each size class were calculated by dividing size-specific chlorophyll-a concentrations by the cell enumeration results (microscope counts and flow cytometry) for each sample. Uncertainty in size-fractionated chlorophyll-a was computed by taking the mean of the absolute value of the difference between the model of Brewin et al. (2010) and the in situ data, relative to the in situ data; whereas uncertainty in intracellular chlorophyll-a for each size class was computed as the average relative deviation in the size-specific intracellular chlorophyll-a concentrations, with respect to its mean. Knowing the relative uncertainty in size-fractionated total chlorophyll-a and intra-cellular chlorophyll-a, allowed the computation of the fractional uncertainty in cell counts, since the fractional error of a quotient is approximately the difference between the fractional errors in the numerator and denominator (Topping, 1962).

The euphotic depth $\left(Z_{\mathrm{eu}}\right)$ for each sample was estimated using the surface chlorophyll-a concentration following Morel et al. (2007). The first optical depth was then computed as $Z_{\text {eu }} / 4.6$. Although the equation in Morel et al. (2007) was derived for case I waters, we used it for all samples, as our objective was only to re-calculate chlorophyll-a per cell for each size class, taking into account only samples collected within the first optical depth of the water column, the layer typically detectable by satellite ocean-colour.

By applying the three-component model of Brewin et al. (2010) to satellite chlorophyll-a data, using model parameters based on our in situ dataset in the first optical depth, the satellite derived size-fractionated chlorophyll-a concentrations were computed on a pixel-by-pixel basis. Then with the size-specific intracellular chlorophyll-a concentrations, derived from our in situ database, cell abundances for each size class were computed on a pixel-by-pixel basis. We applied this approach to a Level 3 Aqua MODIS monthly composite for May 2009 and produced a cell abundance map at a synoptic scale for the study region.

\section{Results}

This study included samples along a trophic gradient within the biogeochemical province eastern North Atlantic Subtropical Gyre (NAST), comprising oligotrophic areas in the mid-Atlantic and eutrophic areas of the Portuguese upwelled coast, also covering the Horseshoe seamounts and the Azores (islands of S. Miguel, Santa Maria and Terceira). Fig. 2 shows the average, standard deviation and median of total chlorophyll-a for the cruises listed in Table 1. The distribution of the data was as follows: $22 \%$ with Chla $\leq 0.1 \mathrm{mg} \mathrm{m}^{-3}, 63 \%$ within the interval $0.1<$ Chla $\leq 1 \mathrm{mg} \mathrm{m}^{-3}$, and $15 \%$ with Chla $>1 \mathrm{mg} \mathrm{m}^{-3}$, the overall average and median being 0.55 and $0.27 \mathrm{mg} \mathrm{m}^{-3}$ respectively. The highest concentrations (8-10 $\mathrm{mg} \mathrm{m}^{-3}$ ) were found over Nazaré Canyon in July 2010, during a strong upwelling event. The majority of the samples (56\%) were taken within the first optical depth.

Similar average and median chlorophyll-a values were recorded for AMT cruises, Seine, Ampere, Gettysburg and Gorringe seamounts and Santa Maria Island. However, phytoplankton assemblages at seamounts were distinct from the AMT: results from flow cytometry showed that the percentage of Synechococcus spp. and Prochlorococcus spp. to total

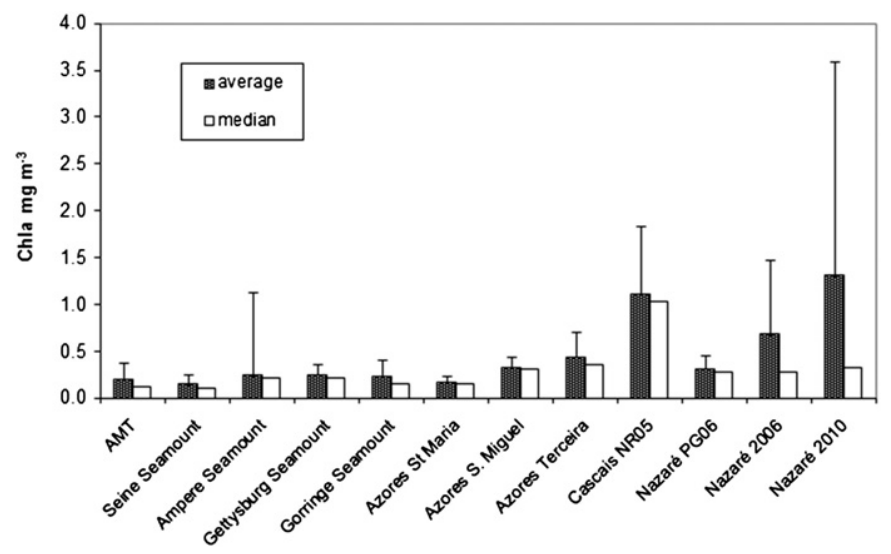

Fig. 2. Chlorophyll-a averages, standard deviation and medians for the various cruises. 
pico- and nano-plankton biovolume was only $6 \%$ for seamounts but $60 \%$ for AMT samples. In Terceira and S. Miguel, a rich and diversified population of coccolithophores was observed, with cell abundances up to $35 \times 10^{3}$ cells $1^{-1}$. The cruises off the Portuguese continental coast (Cascais NR05 and Nazaré) had 30\% of samples with values of Chla $>1 \mathrm{mg} \mathrm{m}^{3}$, this biomass increase was due to upwelling (as in the case of Nazaré) or to the influence of the Tagus Estuary, with incoming riverine nutrients (as is the case of Cascais); micro-plankton fraction, estimated from pigments data, according to Uitz et al. (2006), was on average $77 \%$ occasionally reaching $97 \%$.

The application of the three-component model of Brewin et al. (2010) to our dataset is shown in Fig. 3. Plotted on the y-axis are the concentrations of chlorophyll-a attributed to micro-plankton $\left(C_{m}\right)$, to nano-plankton plus pico-plankton $\left(C_{p, n}\right)$, to nano-plankton alone $\left(C_{n}\right)$ and to pico-plankton alone $\left(C_{p}\right)$, with total chlorophyll-a on the $x$-axis. The fractional contributions of micro-plankton $\left(\mathrm{F}_{\mathrm{m}}\right)$, the sum of nano-plankton and pico-plankton $\left(F_{n, p}\right)$, nano-plankton $\left(F_{n}\right)$, and pico-plankton $\left(F_{p}\right)$ are also shown in the figure as a function of total chlorophyll-a. The parameters of the model include the asymptotic maximum of chlorophyll-a that small size classes can reach ( $C^{\max }$, either $<20 \mu \mathrm{m}$ or $<2 \mu \mathrm{m}$ ), and the initial slope $(S)$ of the curve describing the size-fractionated chlorophyll-a as a function of total chlorophyll-a for the small cells. Values of the model parameters are presented in Table 2. There was a significant difference in model parameters above and below the first optical depth. The value obtained for $C^{\max }$ was always greater below the first optical depth, which is consistent with the increase in chlorophyll-a content per cell with decreasing light levels.

Fig. 4 shows the size-class fractions estimated for the first optical depth, and for the layer below the first optical depth. The model displays similar distributions for micro-plankton (Fig. 4a, e), and combined nano-pico-plankton fractions (Fig. 4b, f) for both optical depths, but with higher mean absolute error (MAE) in the lower layer. The main differences were in the pico- and nano-plankton distributions. At low chlorophyll-a concentrations $\left(<0.1 \mathrm{mg} \mathrm{m}^{-3}\right)$, pico-plankton are dominant in the first optical depth, whereas the fractional contributions of pico- and nano-plankton are similar in the deeper layer.

Fig. 5 shows the size-specific intra-cellular chlorophyll-a concentrations obtained for the whole dataset (Fig. 5a), the first optical
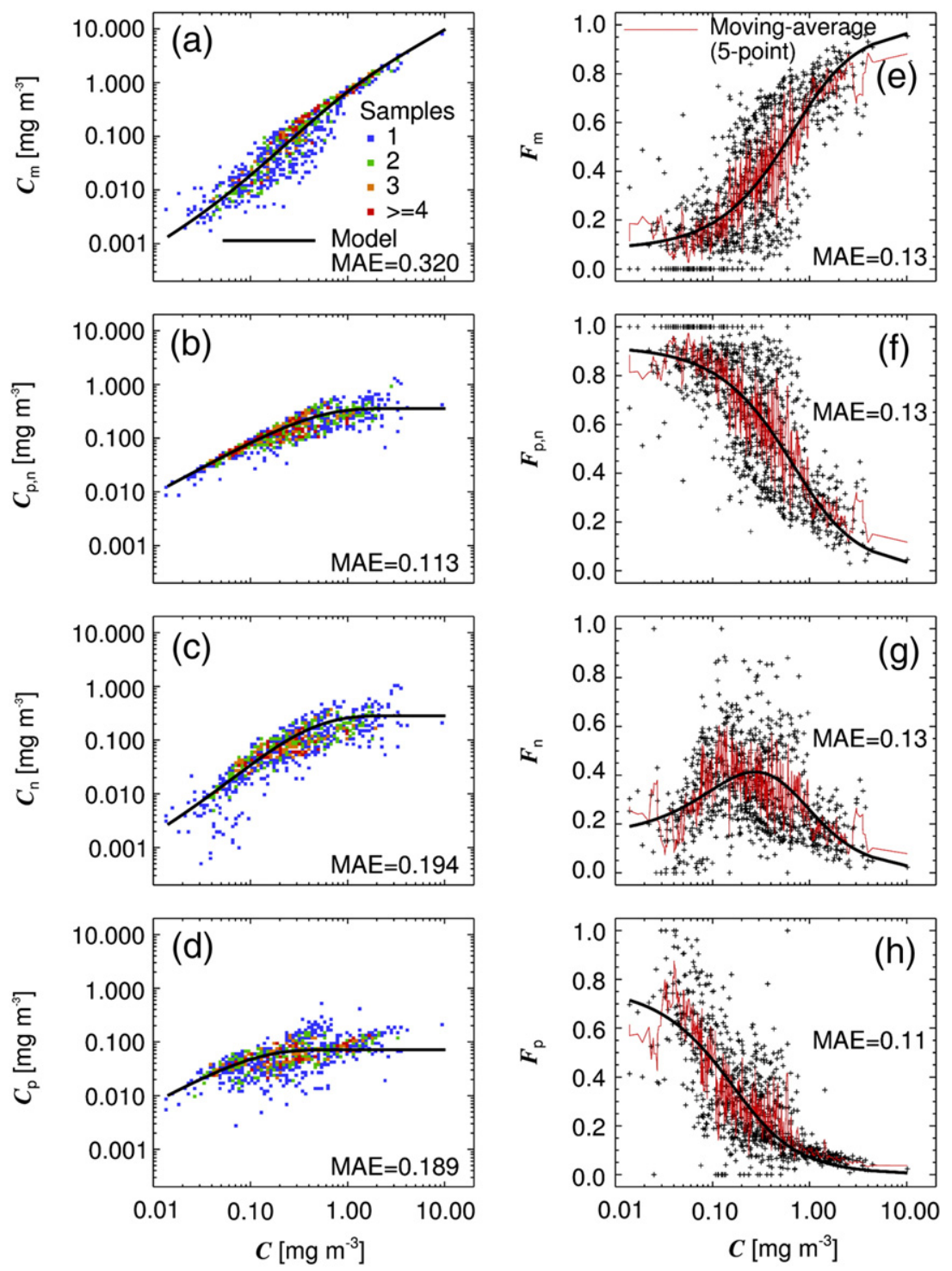

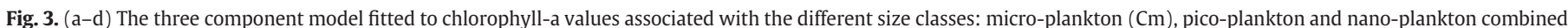

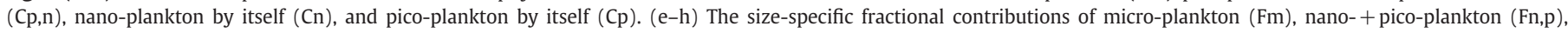

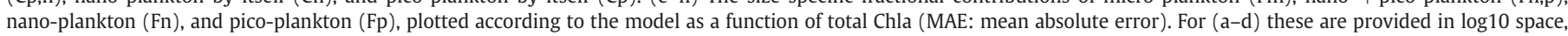
and for $(\mathrm{e}-\mathrm{h})$ in linear space. 
Table 2

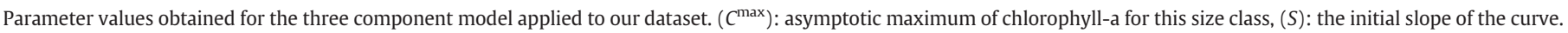
Bracket values represent upper and lower 95\% confidence interval.

\begin{tabular}{|c|c|c|c|}
\hline Model parameters (Brewin et al., 2010) & All data & Above1st optical depth & Below 1st optical depth \\
\hline$C^{\max }$ nano- + pico-plankton & $0.356(0.328$ to 0.386$)$ & $0.280(0.249$ to 0.314$)$ & $0.421(0.380$ to 0.467$)$ \\
\hline$C^{\max }$ pico-plankton & $0.071(0.064$ to 0.079$)$ & $0.058(0.054$ to 0.063$)$ & $0.119(0.098$ to 0.143$)$ \\
\hline$S$ nano- + pico-plankton & 2.587 (2.345 to 2.852$)$ & 3.417 (2.957 to 3.915$)$ & $2.166(1.902$ to 2.458$)$ \\
\hline$S$ of pico-plankton & 10.803 (8.820 to 13.062$)$ & 17.056 (14.693 to 18.646$)$ & $3.910(2.878$ to 5.252$)$ \\
\hline
\end{tabular}

depth (Fig. 5b) and below the first optical depth (Fig. 5c), with the median, mean and mean absolute deviations. The estimated intracellular chlorophyll-a content ranges over 5 orders of magnitude from picoto micro-plankton cells, which is reasonable, as cell volume spans 5 or 6 orders of magnitude from prochlorophytes $\left(0.113 \mu \mathrm{m}^{3}\right.$, Tarran et al., 2001 ) to diatoms or dinoflagellates (for example, Detonula pumila, $13,500 \mu \mathrm{m}^{3}$, and Ceratium furca, $46,000 \mu \mathrm{m}^{3}$, both common species along the Portuguese continental coast and the Azores). The intracellular chlorophyll-a concentration was consistently higher in samples from lower light levels, in all size classes. The median values obtained for all the dataset were $0.004,0.224$ and 26.78 ( pg Chla cell $^{-1}$ ), for pico-, nano- and micro-plankton, respectively, consistent with values from the literature (see Table 3). Moreover, the range of intracellular chlorophyll-a indicated in Table 3, and plotted in Fig. 5a as horizontal coloured bars, for pico-, nano- and micro-plankton size classes, was in accordance with the limit values estimated for each size class. It should be noted the species Skeletonema costatum and Thalassiosira pseudonana (Table 3) have dimensions which do not fit into the micro-plankton cell size category (as a number of other diatom and dinoflagellate species), and, hence, were not considered for Fig. 5a.
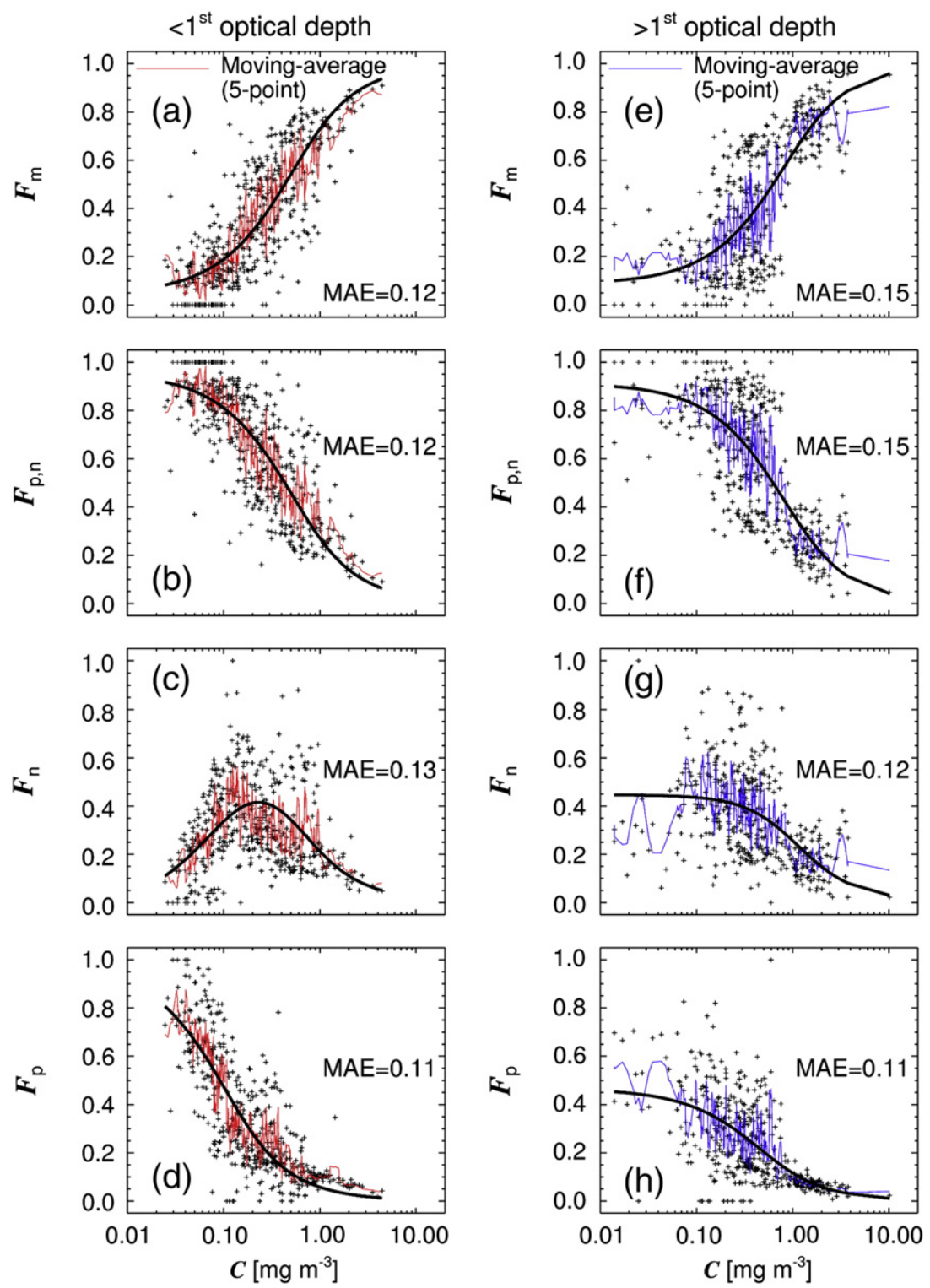

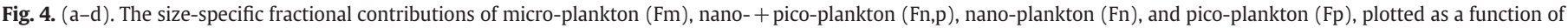

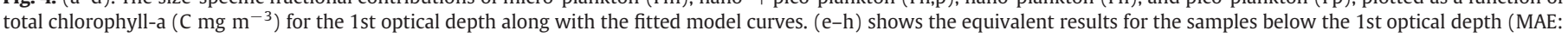
mean absolute error). 

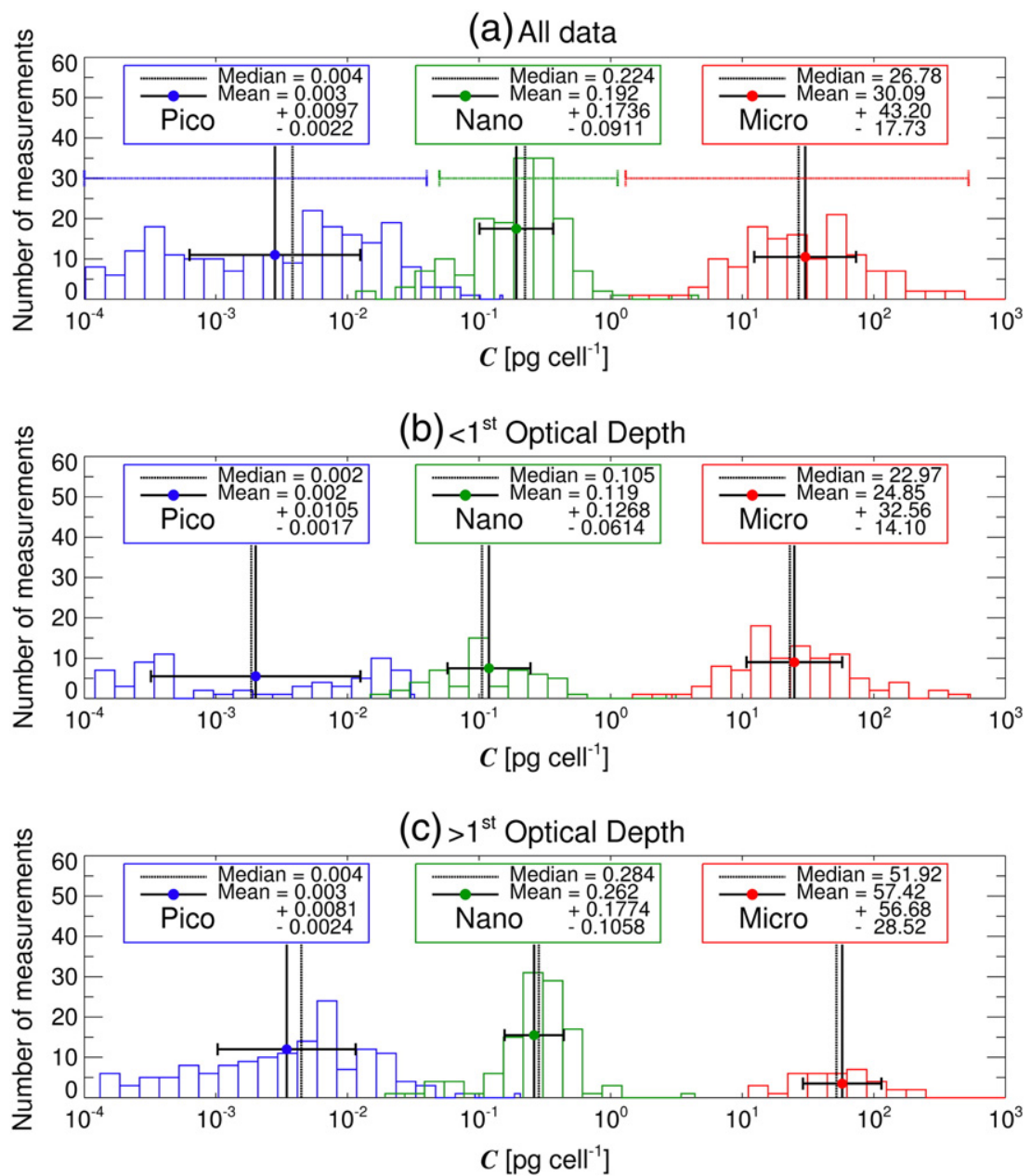

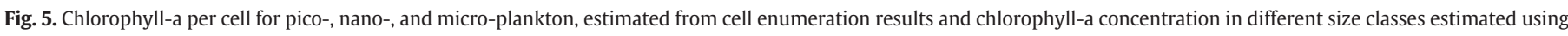

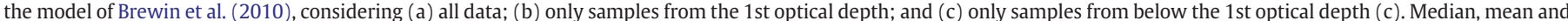

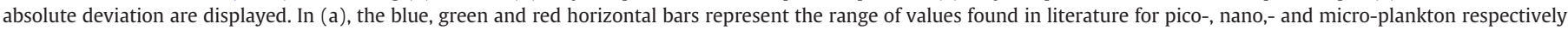
(see Table 3).

A cell-abundance map for each size class, with the corresponding fractional chlorophyll-a concentration, from an Aqua MODIS monthly composite image of May 2009 is shown in Fig. 6. The ranges obtained for the three size classes cell numbers were as follows: for pico-plankton, $9.9 \times 10^{9}$ to $2.9 \times 10^{10}$, for nano-plankton $2.3 \times 10^{7}$ to $1.9 \times 10^{9}$ and for micro-plankton, $8.1 \times 10^{4}$ to $3.2 \times 10^{8}$ cells $\mathrm{m}^{-3}$. Relative uncertainty for each pixel was computed as $59 \%, 41 \%$ and $48 \%$ for pico-, nano- and micro-plankton respectively. Pico-plankton relative contribution to total chlorophyll-a concentration is $60-70 \%$ in the oligotrophic subtropical gyre, micro-plankton attained $70 \%$ along the coast and north of $40^{\circ} \mathrm{N}$, whereas nano-plankton contribution never exceeded $50 \%$, the higher values being located in the regions where neither pico- nor micro-plankton dominated, in terms of chlorophyll-a concentration.

The geographic pattern obtained was consistent with knowledge of the eastern NAST province (Loureiro et al., 2011; Mendes et al., 2011; Mendonça et al., 2012; Oliveira et al., 2009; Silva et al., 2008; Silva et al., 2013; Tarran et al., 2006). The distinction between the more productive sub-polar gyre and the oligotrophic subtropical gyre is clearly seen in the distribution of the three size classes, with each size class being higher by at least one order of magnitude in the sub-polar gyre. Micro-plankton ranged from $8.1 \times 10^{4}$ to $3.2 \times 10^{8}$ cells $\mathrm{m}^{-3}$, being more abundant along the coasts of Portugal, Galicia and Morocco, and above $40^{\circ} \mathrm{N}$. Nano-plankton abundance varied from $2.3 \times 10^{7}$ cells $\mathrm{m}^{-3}$ around $30^{\circ}-32^{\circ} \mathrm{N}$, to approximately $1.9 \times 10^{9}$ cells $\mathrm{m}^{-3}$ along the coast. The map also shows the ubiquitous presence of pico-plankton cells, ranging from $9.9 \times 10^{9}$ to $2.9 \times 10^{10}$ cells $\mathrm{m}^{-3}$, which constitute at least $90 \%$ of cell number throughout the chlorophyll-a range from 0.01 to $10 \mathrm{mg} \mathrm{m}^{-3}$.

The model predicted that the fraction of chlorophyll-a from micro-plankton would be approximately $96 \%$ when total chlorophyll was $10 \mathrm{mg} \mathrm{m}^{-3}$ (the maximum in situ value recorded), even though the cell number would be only $1.3 \%$ of the total. This is due to the four orders of magnitude difference between intracellular chlorophyll-a from micro- and pico-plankton. Pico-plankton have a higher abundance in terms of number of cells regardless of trophic status. However, due to their low intracellular chlorophyll concentrations, this size class contributes little to total chlorophyll biomass at high concentrations. In such environments, larger cells with much higher intracellular chlorophyll contribute the most to total chlorophyll biomass, despite having lower cell counts.

\section{Discussion}

The potential use of ocean-colour remote sensing to map the distribution of phytoplankton has stimulated research on several bio-optical methods, which are based on phytoplankton pigment data, to establish the relative contribution of different PSC or PFT to total chlorophyll-a. The model of Brewin et al. (2010) used in the present study, was applied directly to HPLC data to compute chlorophyll-a from pico-, nano- and micro-plankton. The model was 
Table 3

Intracellular chlorophyll-a concentration (Chla), or divinyl chlorophyll-a (DVChla) from the literature.

\begin{tabular}{|c|c|c|}
\hline Taxons & $\begin{array}{l}\text { Chla or DivChla } \\
\text { pg cell }^{-1}\end{array}$ & Authors \\
\hline \multicolumn{3}{|l|}{ Pico-eukaryotes } \\
\hline Prasinophyte Ostreococcus & 0.04 & Six et al. (2008) \\
\hline \multirow[t]{4}{*}{ Prochlorophytes (DivChla) } & $0.1-1 \times 10^{-3}$ & Bouman et al. (2006) \\
\hline & $0.1-7 \times 10^{-3}$ & Veldhuis and Kraay (2004) \\
\hline & $0.23 \times 10^{-3}$ & Grob et al. (2007) \\
\hline & $0.2-3 \times 10^{-3}$ & \\
\hline \multicolumn{3}{|l|}{ Coccolithophores } \\
\hline Emiliana huxleyi & $0.049-0.283$ & Saunders (1991) \\
\hline E. huxleyi & $0.075-0.1$ & Ra et al. (2010) \\
\hline \multicolumn{3}{|l|}{ Prymnesiophytes } \\
\hline Pavlova lutheri & $0.156-0.288$ & Saunders (1991) \\
\hline \multicolumn{3}{|l|}{ Cryptophyceae } \\
\hline Hemiselmis sff virescens & $0.032-0.194$ & Saunders (1991) \\
\hline Chroomonas salina & $0.30-1.131$ & Saunders (1991) \\
\hline Isochrysis sp. & 0.41 & Our data, not published \\
\hline \multicolumn{3}{|l|}{ Diatoms } \\
\hline Skeletonema costatum & $0.27-0.61$ & Rivkin (1990) \\
\hline Thalassiosira pseudonana & 0.35 & Hitchcock (1982) \\
\hline Nitzschia sp. & 1.32 & Our data, not published \\
\hline Thalassiosira weissflogii & $2.70-5.21$ & Saunders (1991) \\
\hline Cylindrotheca closterium & 8.05 & Ruivo et al. (2011) \\
\hline Dytilum brightwellii & $23-66$ & Rivkin (1990) \\
\hline Detonula pumila & 57 & Our data, not published \\
\hline Rhiizosolenia formosa & $3.33-5.24 \times 10^{2}$ & Richardson et al. (1996) \\
\hline \multicolumn{3}{|l|}{ Dinoflagellates } \\
\hline Scripsiella trochoidea & 1.26 & Our data, not published \\
\hline Amphidinium carterae & 7.27 & Ruivo et al. (2011) \\
\hline S. trochoidea & $9.76-11.18$ & Saunders (1991) \\
\hline Prorocentrum lima & $6.18-8$ & Our data, not published \\
\hline $\begin{array}{l}\text { Protogonyaulax tamarensis } \\
\quad \text { (Alexandrium tamarense) }\end{array}$ & $11-42$ & Rivkin (1990) \\
\hline Akashiwo sanguinea & 54 & Park et al. (2002) \\
\hline Gymnodinium instriatum & 122 & Park et al. (2002) \\
\hline Gymnodinium nelsonii & 307 & Hitchcock (1982) \\
\hline
\end{tabular}

developed for case I waters of the Atlantic Ocean. The present work deals with a specific biogeochemical province, the North Atlantic Subtropical Gyre (NAST, Longhurst et al., 1995) encompassing three trophic regimes; oligo-, meso- and eutrophic (see Fig. 2). The application of the model to a wide assemblage of data from this complex area, proved to be successful, as shown by low mean absolute error between data and model fit.

Nevertheless, the regional values obtained for the model parameters, the asymptotic maximum of chlorophyll-a for the small cells $\left(C^{\max }\right)$ and the initial slope $(\mathrm{S})$, were different from those presented by Brewin et al. (2010) for the case I waters of the Atlantic Ocean as a whole, which had some effect on the relative distribution of size classes as a function of chlorophyll-a. Nano-plankton fraction was higher than the pico-plankton fraction for total chlorophyll-a level greater than $0.2 \mathrm{mg} \mathrm{m}^{-3}$, close to the corresponding value reported by Brewin et al. (2010), but micro-plankton fraction was higher than $50 \%$ for total chlorophyll-a level greater than $0.5 \mathrm{mg} \mathrm{m}^{-3}$, whereas Brewin et al. (2010) indicated that the dominance of micro-plankton started much later $\left(1.3 \mathrm{mg} \mathrm{m}^{-3}\right)$. These differences illustrate the value of tuning the model to the region of interest. Our dataset is more diverse than that of Brewin et al. (2010), in the sense that it contains regions with low chlorophyll-a values, but with seamounts and islands, where circulation patterns are complex. It is thought that current-topography interactions may increase levels of nutrients in oligotrophic waters found around seamounts (White et al., 2007). The relative dominance of micro-plankton fraction at chlorophyll-a concentrations near $0.5 \mathrm{mg} \mathrm{m}^{-3}$, indicated when the model is applied to our data, is supported by microscope observations and by ongoing work on the Portuguese Coast. Around Terceira Island, values of $0.15 \mathrm{mg}$ Chla $\mathrm{m}^{-3}$ corresponded to a combined cell abundance of diatoms and dinoflagellates of 23,000 cells $1^{-1}$. At the Ampère and Seine Seamounts, scanning electron microscopy, showed not only the presence of coccolithophores (Emiliana huxleyi, Gephyrocapsa, Umbiliscosphaera and Calcidiscus) but also the abundance of diatom genera such as Pseudonitzschia, Chaetoceros, Thalassiosira and Thalassiotrix. Specifically for the Seine Seamount, Mendonça et al. (2012) reported a clear seamount effect on microbial community structure and biomass during spring, with an increase in all autotrophic groups (except Procchlorococcus), in relation to reference stations away from seamounts, with an enhanced microplankton cell abundance and species diversity. In conclusion, the application of the Brewin et al. (2010) model to a region as the north-east Atlantic, showed that the application of a conceptual model, derived from a global database to the region is possible, as long as the dataset spans a large range of chlorophyll-a values, and provided the model is re-parameterised for the region using the local data.

The dispersion of the data around the model plots, in particular within the interval 0.1 to $1 \mathrm{mg}$ Chla $\mathrm{m}^{-3}$, for nano-plankton, and around 0.1 for pico-plankton, can probably be attributed to the diverse nature of sampled sites, and concomitantly, to the heterogeneity of phytoplankton assemblages. The set of pigments identified around Azores islands and seamounts included a variety of pigments allocated to nano-plankton classes, such as 19'hexanoyloxyfucoxanthin, 19' butonoyloxyfucoxanthin, prasinoxanthin, alloxanthin and chlorophyll b, but which could also be in part attributed to pico-eukaryotes, detected by flow cytometry in Horseshoe Seamounts samples. In the Azores samples, relatively high concentrations of fucoxanthin and frequent occurrences of peridinin indicated the presence of diatoms and dinoflagellates respectively (confirmed by microscopy cell counts). As for AMT samples, phytoplankton communities were more homogeneous, as $60 \%$ of biovolume was due to Synechococcus and Prochlorococcus, a feature also evident in pigments results, as the mean ratio zeaxanthin/total chlorophyll-a is significantly higher (0.285 in AMT samples versus 0.098 in seamounts plus Azores samples).

When the data were split into samples from above and below the first optical depth, the results hardly differed for micro-plankton fraction: this can be justified by the fact that diatoms, (always the major contributor to micro-plankton in our samples, data not shown), dominate in more turbulent, nutrient-rich environments (Margalef, 1978), and hence their distribution was similar in both optical depths.

The model distributions of the nano- and pico-plankton fractions considered separately for the deeper samples were similar to each other, with a plateau on the lower side of the scale for the nano-plankton (Fig. 4g, h), instead of the higher fraction of pico- and lower fraction of nano-plankton displayed in surface samples (Fig. 4c, d). This implies that the contribution of pico-plankton at low chlorophyll-a values is higher in surface waters than in deeper waters. Uitz et al. (2006) highlighted deviations in the pico- and nano-plankton concentrations, when comparing surface layers with the integrated euphotic zone (see their Fig. 6). Moreover, Brewin et al. (2010) showed a significant correlation between model parameters and optical depth, suggesting that nano-plankton prevails in low chlorophyll-a - low light environments, whereas pico-plankton dominate in low chlorophyll-a, high-light conditions. The existence of a deep nano-flagellate population has also been seen in the tropical North Atlantic (Claustre \& Marty, 1995), the North Pacific gyre (Monger et al., 1999), Mozambique coast (Sá et al., 2013), and in the South Pacific (Ras et al., 2008), though the reason for its existence is still unclear (see Ras et al., 2008). However, it remains to be studied to what extend such apparent depth variations in size class at low 

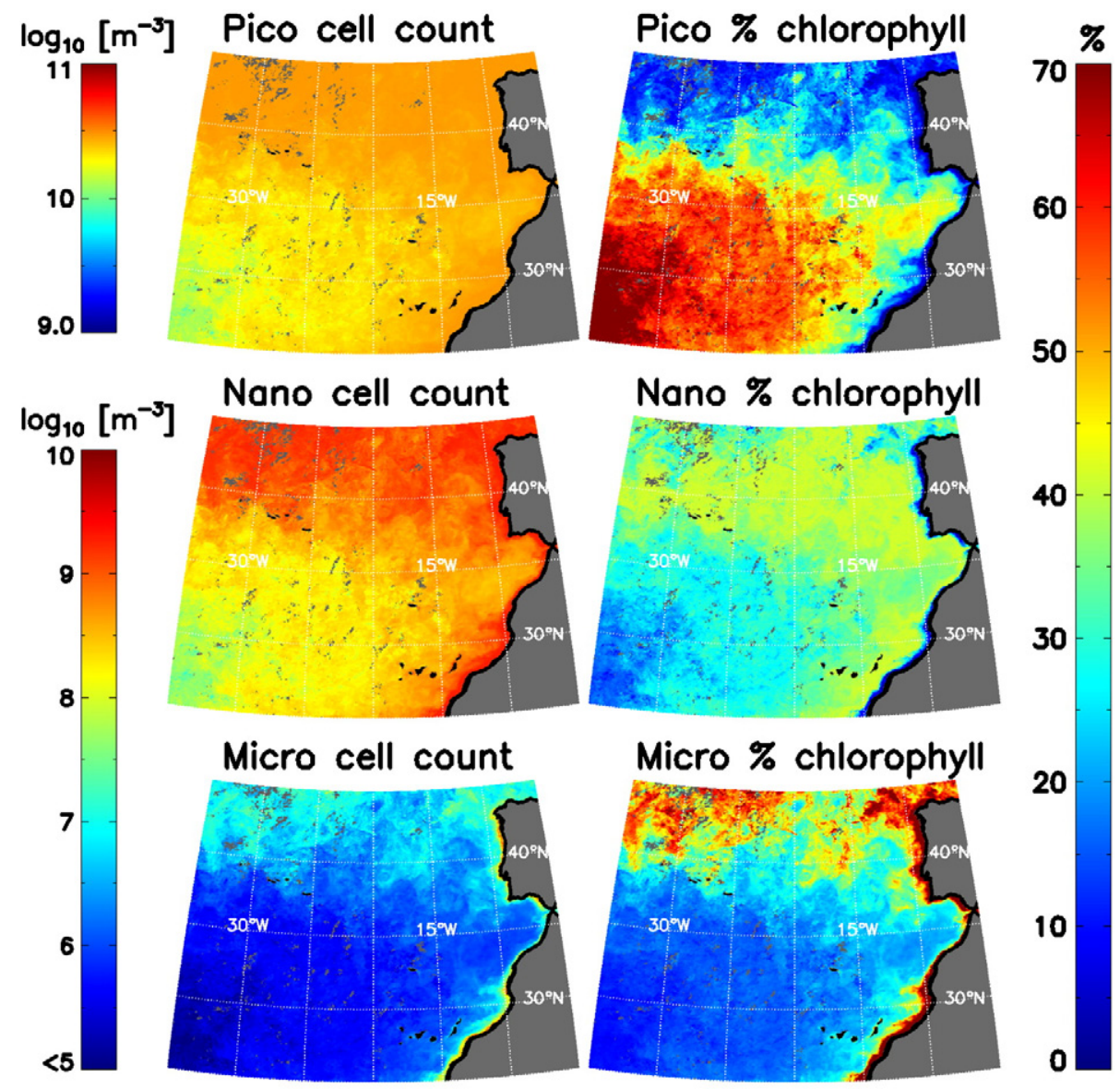

AQUA MODIS May 2009

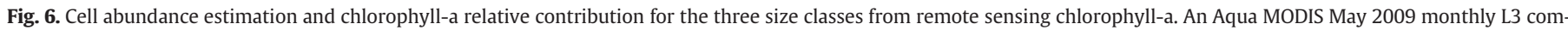

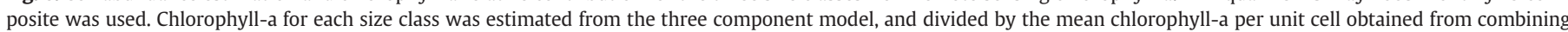
information from the model, microscope cell counts and flow cytometry.

chlorophyll are influenced by the reductionist character of the diagnostic pigment approach, and by higher errors in the model at lower chlorophyll-a concentrations below the first optical depth (see Fig. 4).

Below the first optical depth, higher intracellular chlorophyll-a concentrations (up to 2-fold) were observed for the three size classes (Fig. 5) in relation to samples above the first optical depth. This is expected considering the wealth of literature highlighting increasing intracellular chlorophyll-a with decreasing light levels as a consequence of photoacclimation. The median values obtained for all data (0.004, 0.224 and 26.78 pg Chla cell ${ }^{-1}$ for pico-, nano-, and microplankton respectively) are plausible values, and generally display a unimodal distribution.

Table 3 summarises bibliographic information on intracellular chlorophyll-a for many species along a cell size gradient, mostly obtained in cultures. The dependence of chlorophyll-a content per cell on light intensity, temperature and nutrient availability has been thoroughly discussed (e.g. Geider et al., 1997), explaining the large variability found in the literature. The ranges of intracellular chlorophyll-a we found for the three size-classes are in accordance with literature values (Table 3). There was a wide range of intracellular chlorophyll-a concentrations for micro-plankton species (Fig. 5), which is likely due to the range in cell volume, as it can vary by 4 orders of magnitude within diatoms and dinoflagellates. It is worth pointing out that there is a scarcity of data on intracellular chlorophyll-a concentrations for common marine species.

Pigment-based size-class assignment has an inherent uncertainty, because of two factors: on the one hand, the diagnostic pigments used are not all unique to the phytoplankton taxa with which they are mostly associated (e.g. fucoxanthin, the proxy for diatoms, is present in other classes such as coccolithophores, pelagophytes or chrysophytes; peridinin is not present in all dinoflagellate species and many picoeukaryotes contain fucoxanthin and 19'hexanoyloxyfucoxanthin, Roy et al., 2011). On the other hand, some phytoplankton taxa, which typically belong to a certain size class, may have species that belong to other classes. For example, diatoms, which are classified as microphytoplankton, have species belonging to nano-plankton. Some of these smaller diatoms (e.g. Pseudonitzschia spp. and Thalassiosira spp.) have been reported as common species from the study area (Mendes et al., 2011; Oliveira et al., 2009; Silva et al., 2008; Silva et al., 2013). Here, we have combined a model for partitioning total chlorophyll-a into size classes that is based on diagnostic pigments, with cell abundances measured using flow cytometry or microscope counts for large cells, to infer intracellular pigment concentrations. The results are consistent with values from the literature, providing some indirect validation for the pigment-based method.

Based on the agreement between the model and in situ sizefractioned chlorophyll data (Figs. 3 and 4), as well as the plausible size-specific intracellular chlorophyll-a concentrations derived from them (Fig. 5; Table 3), we have estimated cell abundances for the three size classes from remotely-sensed chlorophyll-a. We used an image (Fig. 6) to illustrate the method. May 2009 was chosen as more than 200 in situ samples were taken in May and early June of 2009, and the vast majority was collected in spring and summer. The image showed a ubiquitous presence of pico-plankton cells, more abundant in the richer waters above $40^{\circ} \mathrm{N}$ and east of $15^{\circ} \mathrm{W}$. The existence of a background population of small-sized cells was postulated by Yentsch 
and Phinney (1989), who suggested that in eutrophic waters, cell size structure was modified by adding larger cells without any apparent loss of the small-sized cells. Later, Chisholm (1992) indicated that in nutrient-rich areas, pico-plankton attain their maximum chlorophyll-a biomass $\left(0.5 \mathrm{mg} \mathrm{Chla} \mathrm{m}^{-3}\right)$, but that under such conditions they represent only a small percentage of total chlorophyll.

Particle size distribution provides important information on ocean ecosystem structure and function (Marañón, 2009). Kostadinov et al. (2009) pointed out that few measurements of particle size distribution have been made in the pelagic ocean and that little is known about its time-space variation. They developed a bio-optical model to estimate particle size distribution from remote sensing, based on the retrieval of the backscattering coefficient spectrum from SeaWiFS normalised water leaving radiance. Despite the differences between the Kostadinov et al. (2009) approach (designed to derive total particle size at global scales) and ours (designed to retrieve phytoplankton size classes at regional scales from chlorophyll-a concentration), there are similarities in the results from both approaches: for example, all three size classes are more abundant in more productive regions, at least by two orders of magnitude. The ranges they found were: for pico-plankton $10^{9}$ to $10^{12}$, for nano-plankton $10^{6}$ to $10^{11}$ and for micro-plankton, $10^{3}$ to $10^{8}$ cells $\mathrm{m}^{-3}$. Our results, estimated for a specific biogeochemical province, fit within the same orders of magnitude, but, with some differences which would be expected considering the characteristics of the eastern North Atlantic, compared with the global ocean, that result in narrower ranges in this study: for pico-plankton, $9.9 \times 10^{9}$ to $2.9 \times 10^{10}$, for nano-plankton $2.3 \times 10^{7}$ to $1.9 \times 10^{9}$ and for microplankton, $8.1 \times 10^{4}$ to $3.1 \times 10^{8}$ cells $\mathrm{m}^{-3}$.

In situ studies from this area confirm these ranges. For microplankton off the Portuguese coast, Oliveira et al. (2009) established $2 \times 10^{8}$ cells $\mathrm{m}^{-3}$ as the threshold for considering a bloom event, reporting a maximum of $3.51 \times 10^{8}$ cells $\mathrm{m}^{-3}$. Studying the Seine Seamount, Mendonça et al. (2012) recorded $4 \times 10^{10}$ cells $\mathrm{m}^{-3}$ for pico-plankton (including Synechococcus, Prochlorococcus and picoeukaryotes) and $1 \times 10^{9}$ cells $\mathrm{m}^{-3}$ for autotrophic nano-flagellates. Veldhuis and Kraay (2004), reported $1.55 \times 10^{11}$ cells $\mathrm{m}^{-3}$ for surface pico-plankton (where more than 95\% was Prochlorococcus) and $3 \times 10^{8}$ cells $\mathrm{m}^{-3}$ for small eukaryotes for the subtropical Atlantic Ocean (their stations 4 and 5). Whereas pico-plankton values of Mendonça et al. (2012) fit within our uncertainty range ( $\pm 60 \%$ ), those reported by Veldhuis and Kraay (2004) surpass it by half an order of magnitude. However, it should be noted that our image represents only a composite for May 2009, aiming at illustrating the possibilities of this approach.

\section{Conclusion}

The results obtained in this work indicate that the estimation of cell abundances from remotely-sensed chlorophyll-a seems to be a promising avenue. Long time-series of remote sensing derived information on size structure offer the possibility to detect shifts in phytoplankton communities as a response to global changes. Moreover, in the context of global change, we have to consider that the ecosystem response to the change may also include changes to the relationship between total chlorophyll and phytoplankton size structure.

The three component model of Brewin et al. (2010) describing the distribution of size-classes as a function of chlorophyll-a was implemented at a relatively large regional scale along a trophic gradient using regional measurements. Though the model holds at the regional scale, some differences in the model parameters and characteristics emerged, which are possibly explained by the ecological characteristics of sampling areas.

Results support the assumption that there is an overall dominance of pico-plankton, in terms of cell numbers from oligotrophic to eutrophic regions. More productive areas present higher cell numbers in all cell size classes, but the increase in chlorophyll-a is given by the increment in chlorophyll-a fraction due to larger cells.

The approach presented in this work, whereby the abundance of cell-size classes of phytoplankton can be derived from satellite imagery is a novel and promising contribution to the understanding of the biogeochemical role of phytoplankton in our planet.

\section{Acknowledgements}

The authors would like to thank Instituto Hidrográfico, Portugal, (for Nazaré and Gorringe cruises), NIOZ (for Nazaré PG06 cruise), Dr. Bernd Christiansen (Universität Hamburg) for inviting M. Kaufmann to participate in cruise POS384 and Project "Caracterização das massas de água costeiras das ilhas de Santa Maria e de São Miguel" funded by Direcção Regional do Ordenamento do Território e Recursos Hídricos for the Azores samples. We also thank Vera Veloso for helping with microalgae cultures.

This research is funded by CoastColour (ESA project) and HabSpot (FCT Project, PTDC/MAR/100348/2008), Vanda Brotas received a sabbatical grant from FCT (SFRH/BSAB/1044/2010). Ana Brito was funded by a Portuguese Post-doc grant from FCT (BPD/63017/2009). This study was also supported by the Fundação para a Ciência e a Tecnologia (PEst-OE/MAR/UI0199/2011).

This study was supported by the UK Natural Environment Research Council National Capability funding to Plymouth Marine Laboratory and the National Oceanography Centre, Southampton. This is contribution number 217 of the AMT programme. This is a contribution to the Ocean Colour Climate Change Initiative of the European Space Agency.

The authors also acknowledge the comments and suggestions of two anonymous referees. I would like to dedicate this paper in the memory of my father, JC Almeida Gonçalves, medical doctor. His life and his absolute faith in science were an inspiration to me. Vanda Brotas.

\section{References}

Aiken, J., Pradhan, Y., Barlow, R., Lavender, S., Poulton, A., Holligan, P., et al. (2009). Phytoplankton pigments and functional types in the Atlantic Ocean: A decadal assessment, 1995-2005. AMT Special Issue. Deep-Sea Research Part II, 56, 899-917.

Alvain, S., Moulin, C. Dandonneau, Y., \& Breon, F. M. (2005). Remote sensing of phytoplankton groups in case 1 waters from global SeaWiFS imagery. Deep-Sea Research Part I, 1(52), 1989-2004.

Barlow, R., Stuart, V., Lutz, V., Sessions, H., Sathyendranath, S., Platt, T., et al. (2007). Seasonal pigment patterns of surface phytoplankton in the subtropical Southern Hemisphere. Deep-Sea Research Part I, 54, 1687-1703.

Blackford, J. C., Allen, J. I., \& Gilbert, F. J. (2004). Ecosystem dynamics at six contrasting sites: A generic modelling study. Journal of Marine Systems, 52(1-4), 191-215.

Bouman, H., Platt, T., Sathyendranath, S., \& Stuart, V. (2005). Dependence of light-saturated photosynthesis on temperature and community structure. Deep Sea Research Part I, 52, 1284-1299.

Bouman, H. A., Ulloa, O., Scanlan, D., Zwirglmaier, C., Li, W. K. W., Platt, T., et al. (2006). Oceanographic basis of the global surface distribution of Prochlorococcus ecotypes. Science, 312, 918-921.

Bowler, C., Karl, D. M., \& Colwell, R. (2009). Microbial oceanography in a sea of opportunity. Nature, 459, 180-184.

Brewin, R. J. W., Devred, E., Sathyendranath, S., Lavender, S. J., \& Hardman-Mountford, N. J. (2011a). Model of phytoplankton absorption based on three size classes. Applied Optics, 50(22), 4353-4364.

Brewin, R. J. W., Hardman-Mountford, N. J., Lavender, S. J., Raitsos, D. E., Hirata, T., Uitz, J., et al. (2011b). An intercomparison of bio-optical techniques for detecting dominant phytoplankton size class from satellite remote sensing. Remote Sensing of Environment, 115(2), 325-339.

Brewin, R. J. W., Hirata, T., Hardman-Mountford, N. J., Lavander, S. J., Sathyendranath, S., \& Barlow, R. (2012). The influence of the Indian Ocean Dipole on interannual variations in phytoplankton size structure as revealed by Earth Observation. Deep-Sea Research Part II, 77-80, 117-127.

Brewin, R. J. W., Sathyendranath, S., Hirata, T., Lavender, S., Barciela, R. M., \& Hardman-Mountford, N. J. (2010). A three-component model of phytoplankton size class for the Atlantic Ocean. Ecological Modelling, 221, 1472-1483.

Bricaud, A., Claustre, H., Ras, J., \& Oubelkheir, K. (2004). Natural variability of phytoplankton absorption in oceanic waters: Influence of the size structure of algal populations. Journal of Geophysical Research, 109, C11010.

Brotas, V., \& Plante-Cuny, M. R. (1996). Identification et quantification des pigments chlorophylliens et caroténoïdes des sédiments marins: un protocole d'analyse par HPLC. Oceanologica Acta, 19, 623-634. 
Chisholm, S. (1992). Phytoplankton size. In P. G. Falkowski, \& A. D. Woodhead (Eds.), Primary productivity and biogeochemical cycles in the sea (pp. 213-237). New York: Plenum Press.

Ciotti, A. M., \& Bricaud, A. (2006). Retrievals of a size parameter for phytoplankton and spectral light absorption by coloured detrital matter from water-leaving radiances at SeaWiFS channels in a continental shelf off Brazil. Limnology and Oceanography: Methods, 4, 237-253.

Claustre, H. (1994). Phytoplankton pigment signatures of the trophic status in various oceanic regimes. Limnology and Oceanography, 39, 1206-1211.

Claustre, H., \& Marty, J. C. (1995). Specific phytoplankton biomasses and their relation to primary production in the tropical North Atlantic. Deep Sea Research, 42, 1475-1493.

Dandonneau, Y., Deschamps, P. -Y., Nicolas, J. -M., Loisel, H., Blanchot, J., Montel, Y. et al. (2004). Seasonal and interannual variabilityof ocean color and composition of phytoplankton communities in the North Atlantic, equatorial Pacific and South Pacific. Deep-Sea Research Part II, 51, 303-318.

Devred, E., Sathyendranath, S., \& Platt, T. (2009). Decadal changes in ecological provinces of the northwest Atlantic Ocean revealed by satellite observations. Geophysical Research Letters, 36, L19607.

Devred, E., Sathyendranath, S., Stuart, V., \& Platt, T. (2011). A three component classification of phytoplankton absorption spectra: Application to ocean-color data. Remote Sensing of Environment, 115, 2255-2266.

Finkel, Z. V., Beardall, J., Flynn, K. J., Quigg, A., Rees, T. A. V., \& Raven, J. A. (2010). Phytoplankton in a changing world: Cell size and elemental stoichiometry. Journal of Plankton Research, 32(1), 119-137.

Geider, R. J., MacIntyre, H. L., \& Kana, T. M. (1997). A dynamic model of phytoplankton growth and acclimation: Responses of the balanced growth rate and chlorophyll a: carbon ratio to light, nutrient-limitation and temperature. Marine Ecology Progress Series, 148, 187-200.

Gibb, S. W., Barlow, R. G., Cummings, D. W., Rees, N. W., Trees, C. C., Holligan, P., et al. (2000). Surface phytoplankton pigment distributions in the Atlantic Ocean: An assessment of basin scale variability between 501N and 501S. Progress in Oceanography, 45, 339-368.

Grob, C., Ulloa, O., Claustre, H., Huot, Y., Alarcon, G., \& Marie, D. (2007). Contribution of picoplankton to the total particulate organic carbon concentration in the eastern South Pacific. Biogeosciences, 4, 837-852.

Hillebrand, C., Dürselen, C. D., Kirschtel, D., Pollingher, U., \& Zohary, T. (1999). Biovolume calculation for pelagic and benthic microalgae. Journal of Phycology, 35, 403-424.

Hirata, T., Aiken, J., Smyth, T. J., Hardman-Mountford, N., \& Barlow, R. G. (2008). An absorption model to derive phytoplankton size classes from satellite ocean colour. Remote Sensing of Environment, 112(6), 3153-3159.

Hirata, T., Hardman-Mountford, N. J., \& Brewin, R. J. W. (2012). Comparing satellite-based phytoplankton classification methods. EOS, Transactions American Geophysical Union, 93(6), 59-60.

Hirata, T., Hardman-Mountford, N. J., Brewin, R. J. W., Aiken, J., Barlow, R., Suzuki, K., et al. (2011). Synoptic relationships between surface chlorophyll-a and diagnostic pigments specific to phytoplankton functional types. Biogeosciences, 8, 311-327.

Hitchcock, G. L. (1982). A comparative study of size-dependent organic composition of marine diatoms and dinoflagellates. Journal of Plankton Research, 4(2), 364-377.

Hooker, S. B., Clementson, L., Thomas, C. S., Schlüter, L., Allerup, M., Ras, J., et al. (2012). The Fifth SeaWiFS HPLC Analysis Round-Robin Experiment (SeaHARRE-5). NASA Technical Memoradum 2012-217503, NASA Goddard Space Flight Center, Greenbelt, Maryland.

Jeffrey, S. W., Mantoura, R. F. C., \& Wright, S. W. (2007). Phytoplankton pigments in oceanography: Guidelines to modern methods. Monographs on oceanographic methodology, Vol. 10, Paris: UNESCO Publishing.

Kostadinov, T. S., Siegel, D. A., \& Maritorena, S. (2009). Retrieval of the particle size distribution from satellite ocean color observations. Journal of Geophysical Research, 114, C09015.

Kostadinov, T. S., Siegel, D. A., \& Maritorena, S. (2010). Global variability of phytoplankton functional types from space: Assessment via the particle size distribution. Biogeosciences, 7, 3239-3257.

Kraay, G. W., Zapata, M., \& Veldhuis, M. J. W. (1992). Separation of chlorophylls c1, c2, and $\mathrm{c} 3$ of marine phytoplankton by reversed-phase-C18-high-performance liquid chromatography. Journal of Phycology, 28, 708-712.

Le Quéré, C., Harrison, S. P., Prentice, I. C., Buitenhuis, E. T., Aumont, O., Bopp, L., et al. (2005). Ecosystem dynamics based on plankton functional types for global ocean biogeochemistry models. Global Change Biology, 11, 2016-2040.

Longhurst, A., Sathyendranat, S., Platt, T., \& Caverhill, C. (1995). An estimate of global primary production in the ocean from satellite radiometer data. Journal of Plankton Research, 17, 1245-1271.

Loureiro, S., Reñé, A., Garcés, E., Camp, J., \& Vaqué, D. (2011). Harmful algal blooms (HABs), dissolved organic matter (DOM), and planktonic microbial community dynamics at a near-shore and a harbour station influenced by upwelling (SW Iberian Peninsula). Journal of Sea Research, 65, 401-413.

Marañón, E. (2009). Phytoplankton size structure. In J. H. Steele, K. K. Turekian, \& S. A. Thorpe (Eds.), Encyclopedia of ocean sciences (2nd ed.). Oxford: Academic Press.

Margalef, R. (1978). Life-forms of phytoplankton as survival alternatives in an unstable environment. Oceanologica Acta, 1, 493-509.

Mendes, C. R., Cartaxana, P., \& Brotas, V. (2007). HPLC determination of phytoplankton and microphytobenthos pigments: Comparing resolution and sensitivity of a C18 and a C8 method. Limnology and Oceanography Methods, 5, 363-370.

Mendes, C. R., Sá, C., Vitorino, J., Borges, C., \& Brotas, V. (2011). Spatial distribution of phytoplankton communities in the Nazaré submarine canyon region (Portugal): HPLC-CHEMTAX approach. Journal of Marine Systems, 87(1), 90-101.

Mendonça, A., Arístegui, J., Vilas, J. C., Montero, M. F., Ojeda, A., Espino, M., et al. (2012). Is there a seamount effect on microbial community structure and biomass? The case study of Seine and Sedlo Seamounts (northeast Atlantic). PLoS One, 7(1), e29526.
Monger, B. C., Landry, M. R., \& Brown, S. L. (1999). Feeding selection of heterotrophic marine nanoflagellates based on the surface hydrophobicity of their picoplankton prey. Limnology and Oceanography, 44(8), 1917-1927.

Morel, A., Huot, Y., Gentili, B., Werdell, P. J., Hooker, S. B., \& Franz, B. A. (2007) Examining the consistency of products derived from various ocean color sensors in open ocean (case 1) waters in the perspective of a multi-sensor approach. Remote Sensing of Environment, 111, 69-88.

Nair, A., Sathyendranath, S., Platt, T., Morales, J., Stuart, V., Forget, M. -H., et al. (2008) Remote sensing of phytoplankton functional types. Remote Sensing of Environment, 112, 3366-3375.

Oliveira, P. B., Moita, T., Silva, A., Monteiro, I. T., \& Palma, A. S. (2009). Summer diatom and dinoflagellate blooms in Lisbon Bay from 2002 to 2005: Pre-conditions inferred from wind and satellite data. Progress in Oceanography, 83, 270-277.

Park, M. G., Cooney, S. K., Yih, W., \& Coats, D. W. (2002). Effects of two strains of the parasitic dinoflagellate Amoebophrya on growth, photosynthesis, light absorption, and quantum yield of bloom-forming dinoflagellates. Marine Ecology Progress Series, 277, 281-292.

Platt, T., \& Sathyendranath, S. (2008). Ecological indicators for the pelagic zone of the ocean. Remote Sensing of Environment, 112, 3426-3436.

Platt, T., Sathyendranath, S., \& Fuentes-Yaco, C. (2007). Biological oceanography and fisheries management: Perspective after ten years. ICES Journal of Marine Science $64,863-869$.

Ra, K., Hiroyuk, K., \& Shiraiwa, Y. (2010). Mg isotopes in chlorophyll-a and coccoliths of cultured coccolithophores (Emiliania huxleyi) by MC-ICP-MS. Marine Chemistry, $122,130-137$

Raitsos, D. E., Lavender, S. J., Maravelias, C. D., Haralambous, J., Richardson, A. J., \& Reid, P. C. (2008). Identifying four phytoplankton functional types from space: An ecological approach. Limnology and Oceanography, 53(2), 605-613.

Ras, J., Claustre, H., \& Uitz, J. (2008). Spatial variability of phytoplankton pigment distributions in the subtropical South Pacific Ocean: Comparison between in situ and predicted data. Biogeosciences, 5, 353-369.

Richardson, T. A., Ciotti, A. M., Cullen, J. J., \& Villareal, T. A. (1996). Physiological and optical properties of Rhizosolenia formosa (Bacillariophyceae in the context of open-ocean vertical migration. Journal of Phycology, 32, 741-757.

Rivkin, R. B. (1990). Photadaptation in marine phytoplankton: Variations in ribulose 1,5-biphosphate activity. Marine Ecology Progress Series, 62, 61-72.

Roy, S., Llewellyn, C., Egelend, E. S., \& Johnsen, G. (2011). Phytoplankton pigments Characterization and applications in oceanography. Cambridge University Press.

Ruivo, M., Amorim, A., \& Cartaxana, P. (2011). Effects of growth phase and irradiance on phytoplankton pigment ratios: Implications for chemotaxonomy in coastal waters. Journal of Plankton Research, 33, 1012-1022.

Ryther, J. H. (1969). Photosynthesis and fish production in the sea. The production of organic matter and its conversion to higher forms of life vary throughout the world ocean. Science, 166, 72-76.

Sá, C., Leal, M. C., Silva, A., Nordez, S., André, E., Paula, J., et al. (2013). Variation of phytoplankton assemblages along the Mozambique coast as revealed by HPLC and microscopy. Journal of Sea Research, 79, 1-11.

Sathyendranath, S., Stuart, V., Cota, G., Maass, H., \& Platt, T. (2001). Remote sensing of phytoplankton pigments: A comparison of empirical and theoretical approaches. International Journal of Remote Sensing, 22, 249-273.

Sathyendranath, S., Watts, L., Devred, E., Platt, T., Caverhill, C., \& Maass, H. (2004). Discrimination of diatoms from other phytoplankton using ocean-colour data. Marine Ecology Progress Series, 272, 59-68.

Saunders, R. (1991). Comparative study of the biochemical composition of selected species of phytoplankton in the Plymouth Culture Collection. Plymouth, UK: Plymouth Marine Laboratory Undergraduate Dissertation.

Sieburth, J. M., Smetacek, V., \& Lenz, J. (1978). Pelagic ecosystem structure: Heterotrophic compartments of the plankton and their relationship to plankton size fractions. Limnology and Oceanography, 23, 1256-1263.

Silva, A., Mendes, C. R., Palma, S., \& Brotas, V. (2008). Short time variation of phytoplankton succession, during one year, in Lisbon Bay (Portugal) as revealed by microscopy cells counts and HPLC pigment analysis. Estuarine, Coastal and Shelf Science, 79, 230-238.

Silva, A., Brotas, V., Valente, A, Sá, C. Diniz, T, Patarra, R. F., et al. (2013). Coccolithophores species as indicators of oceanographic conditions in the Azores region. Estuarine and Coastal Shelf Science, 118, 50-59.

Six, C., Finkel, Z. V., Rodriguez, F., Marie, D., Partensky, F., \& Campbell, D. A. (2008) Contrasting photoacclimation costs in ecotypes of the marine eukaryotic picoplankter Ostreococcus. Limnology and Oceanography, 53(1), 255-265.

Tarran, G. A., Heywood, J. L., \& Zubkov, M. V. (2006). Latitudinal changes in the standing stocks of nano- and picoeukaryotic phytoplankton in the Atlantic Ocean. Deep-Sea Research Part II, 53, 1516-1529.

Tarran, G. A., Zubkov, M. V., Sleigh, M. A., Burkill, P. H., \& Yallop, M. (2001). Microbial community structure and standing stocks in the NE Atlantic in June and July of 1996. Deep-Sea Research Part II, 48(4-5), 963-985.

Taylor, B. B., Torrecilla, E., Bernhardt, A., Taylor, M. H., Peeken, I., Röttgers, R., et al. (2011). Bio-optical provinces in the eastern Atlantic Ocean and their biogeographical relevance. Biogeosciences Discuss, 8, 7165-7219.

Topping, J. (1962). Errors of observations and their treatment. Whistable, Great Britain: Latimer Trend and Co. Ltd.

Uitz, J., Claustre, H., Morel, A., \& Hooker, S. B. (2006). Vertical distribution of phytoplankton communities in open ocean: An assessment based on surface chlorophyll. Journal of Geophysical Research, 111, CO8005.

Veldhuis, M. J. W., \& Kraay, G. W. (2004). Phytoplankton in the subtropical Atlantic Ocean: Towards a better assessment of biomass and composition. Deep-Sea Research Part I, 51, 507-530. 
Vidussi, F., Claustre, H., Manca, B. B., Luchetta, A., \& Marty, J. C. (2001). Phytoplankton pigment distribution in relation to upper thermocline in the eastern Mediterranean Sea during winter. Journal of Geophysical Research, 106, 19939-19956.

White, M., Bashmachnikov, I., Arístegui, J., \& Martins, A. (2007). Physical processes and seamount productivity. In T. J. Pitcher (Ed.), Seamounts: Ecology, fisheries \& conservation (pp. 63-84). Oxford, UK: Blackwell Publishing.

Worden, A. Z., \& Not, F. (2008). Ecology and diversity of picoeukaryotes. In D. L Kirchman (Ed.), Microbial ecology of the oceans, 2nd ed., (pp. 159-205). John Wiley \& Sons.
Yentsch, C. S., \& Phinney, D. A. (1989). A bridge between ocean optics and microbial ecology. Limnology and Oceanography, 34(8), 1694-1705.

Yoder, J. A., Doney, S. C., Siegel, D. A., \& Wilson, C. (2010). Study of marine ecosystems and biogeochemistry now and in the future: Examples of the unique contributions from space. Oceanography, 23(4), 104-117.

Zapata, M., Rodriguez, F., \& Garrido, J. L. (2000). Separation of chlorophylls and carotenoids from marine phytoplankton: A new HPLC method using a reversed phase C8 column and pyridine-containing mobile phases. Marine Ecology Progress Series, 195, 29-45. 